Monotonous work may not destroy individuality since as a result of the advance of education the average British workman is learning to employ his leisure properly. Mr. Watson contends that machinery has lightened work so that the worker leaves the factory at the end of the day mentally fresh and often eager to apply his mind to other spheres of activity.

\section{Oil and Pollution}

The desire for an international conference on the oil pollution of the seas has become increasingly evident since the failure of the Oil in Navigable Waters Act of 1922 and the Washington Conference of 1926 to cope with the trouble, which not only affects sea-birds and fish but also involves economic loss and other dangers. The menace and trouble to bird-life has been abundantly shown (Bird Notes and News, 15, No. 6. 1933) by bird-protection societies in Great Britain, and at the request of the Board of Trade, the Royal Society for the Prevention of Cruelty to Animals has circulated its coastal branches for recent data to indicate increase or decrease in recent years. Prof. Rudolf Drost says the menace to birds at Heligoland is at its greatest in winter, and it is not unusual to find 50 dead guillemots in a single day (Bird Notes and News, 15, No. 5), and Dr. G. W. Field (Bird Lore, Sept.-Oct., 1932) says a continuous oil-film stretches at least 500 miles outside New York harbour and off Cherbourg, France, and a continuous sheet 100 miles in diameter was seen by him between France and Newfoundland. In a pamphlet on "The Bacteriology of Pollution in Relation to Inshore Fisheries", issued by the South Wales Sea Fisheries District Committee, 1930, Commander E. Kirkpatrick, fishery officer, directed attention to the failure of inshore fishermen through pollution, and to eye-trouble and blistered arms of stake-net fishermen in the South Wales area due to contact with glutinous, oily and acid matter when cleansing nets from the tarry residue borne on the tide. The oil trouble was first noticed on the Lancashire coast affecting sea-birds in 1916, when it was attributed to oil from submarines, but in P. J. Ralfe's 1931-1932 report on the "Birds of the Isle of Man" it is noted that "very little has been heard of oiled birds".

\section{Sensitivity of Fish to Earthquakes}

Two Japanese seismologists, Dr. Shinkishi Hatai and Dr. Noboru Abe, observed that catfish (Siluridæ) in natural conditions showed signs of restlessness about six hours before earthquake disturbances were registered on their recording apparatus. Since catfish are, ordinarily, placid unresponsive creatures, experiments were made to test this seeming responsiveness (Science Service, Washington, D.C.). Catfish placed in an aquarium were tested three times a day by tapping on the supporting table. When no earthquake was impending, the fish moved lazily or not at all; but about six hours before a shock the fish jumped when the table was tapped, and sometimes swam about agitatedly for a time before settling down upon the bottom again. Several months' testing showed that in a period when 178 earthquakes of all degrees of severity had been recorded, the fish had correctly predicted 80 per cent of the shocks. They showed no discrimination in their movements between slight local shocks and more serious distant shocks. The experimenters think that the catfish are made sensitive through electrical changes in the earth, since it was only when the aquarium was electrically earthed, through the drain-pipe, that they responded to a coming earthquake.

\section{Announcements}

Prof. F. J. M. STratron, professor of astrophysics in the University of Cambridge, has been elected a corresponding member of the Instituto de Coimbra, Portugal.

Mr. E. F. Reid has been awarded the Coopers Hill War Memorial prize of the Institution of Civil Engineers for 1932 for his paper on "Failures in Steel and Cast-Iron Mains and Provision for their Protection". This prize was founded by the Coopers Hill Society in memory of Coopers Hill men who lost their lives in the War.

Sir JAmes Frazer has been offered a grant of $\mathfrak{\$ 4 0 0}$ a year for three years by the Drapers' Company, as a mark of the Company's recognition of his conspicuous contributions and distinguished services to science and to literature, for the purpose of providing himself with such expert secretarial assistance as will enable him to continue the scheme of work on which he has recently embarked and which, by reason of his failing eyesight, he might otherwise be unable to complete.

Applications are invited for the following appointments, on or before the dates mentioned:-An assistant to take charge of the Electrical Engineering Department in the Technical College, WolvertonThe Principal (Dec. 1). A veterinary officer to the Herefordshire County Council and the Hereford City Council-The Clerk of the County Council, Shirehall, Hereford (Dec. 2). A medical inspector of factories-The Industrial Division, Home Office, London, S.W.1 (Dec. 4). A woman bacteriologist and lecturer in bacteriology at the Royal Free Hospital and London (R.F.H.) School of Medicine for Women--The Secretary, Royal Free Hospital, Gray's Inn Road, London, W.C.1 (Dec. 4). A chief veterinary officer to the Staffordshire County Council -The Clerk of the County Council, Stafford (Dec. 5). Two veterinary inspectors to the Derbyshire County Council-The Clerk of the County Council, County Offices, St. Mary's Gate, Derby (Dec. 11). A scientific research fellow at Girton College, Cambridge--The Secretary (Feb. 1). A publicity and organising officer for the National Institute of Industrial Psychology, Aldwych. House, London, W.C.2-The Principal. A regius professor of botany in the University of Aberdeen-The Private Secretary, Scottish Office, Whitehall, London, S.W.1. 